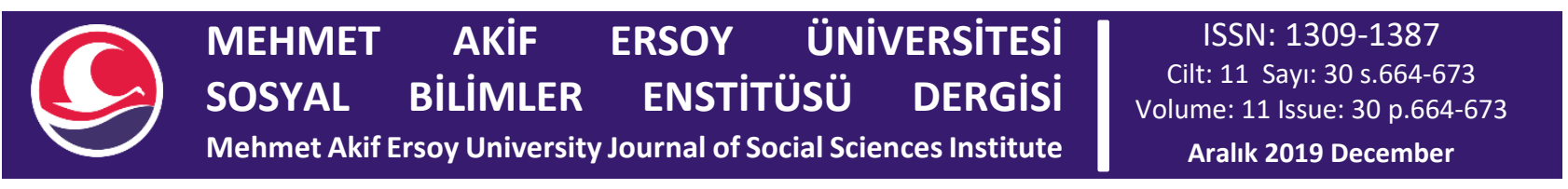

\title{
ÇALIŞAN MUTLULUĞUNUN VE İŞE BAĞLILIĞIN ÖRGÜT PERFORMANSINA ETKİSI
}

\section{THE EFFECT OF HAPPINESS OF EMPLOYEES AND COMMITMENT TO WORK ON ORGANIZATIONAL PERFORMANCE}

\author{
Aysun YEŞİLTAŞ ${ }^{1}$, Sibel ŞAHIN ${ }^{2}$, Gözde SEREZLI ${ }^{3}$
}

1. Süleyman Demirel Üniversitesi, Sağlık Yönetimi, Doktora Öğrencisi, pelineren78@hotmail.com, https://orcid.org/0000-0002-2023-1485

2. Öğr. Gör., Kastamonu Üniversitesi, Daday Nafi ve Ümit Çeri Meslek Yüksekokulu, Sağlık Kurumları İşletmeciliği, sibelsahin@kastamonu.edu.tr, https://orcid.org/0000-0002-1834-2434

3. Öğr. Gör., Kastamonu Üniversitesi, Daday Nafi ve Ümit Çeri Meslek Yüksekokulu, Bankacılık ve Sigortac1lık, gserezli@kastamonu.edu.tr, https://orcid.org/0000-0003-0573-839X

Makale Türï

Araştırma Makalesi

Başvuru Tarihi

18.04.2019

Yayına Kabul Tarihi 22.11.2019

DOI

10.20875/makusobed.55541
Article Type Research Article

Application Date 04.18 .2019

Admission Date 11.22.2019

Öz

Bu çalışmada, çalışan mutluluğunun ve işe bağl1lığın örgüt performansı üzerindeki etkisinin incelenmesi amaçlanmıştır. Bu kapsamda çalışmada sağlık çalışanların mutluluk düzeylerini ölçmek için "Oxford Mutluluk Ölçeği"; işe bağlılıklarını ölçmek için "Utrecht İşe Bağlılık Ölçeği” ve örgüt performansını ölçmek için “Örgütsel Performans Ölçeği” kullanılmıştır. Tanımlayıcı türde olan araştırmanın evrenini Kastamonu il merkezinde bulunan özel bir hastanenin sağlık çalışanları oluşturmuştur. Çalışmaya 93 sağlık personeli gönüllü olarak katılmıştır. Araştırmanın sonuçlarına göre, lisansüstü eğitime sahip çalışanların lise mezunu çalışanlara, hekimlerin ise hemşirelere göre daha mutlu oldukları görülmüştür. Teknisyenlerin hekim ve hemșirelere göre örgüt performansını düșük olarak değerlendirdikleri ortaya çıkmıștır. Katılımcıların işe bağlılık algılarının örgüt performansı tutumları üzerindeki etkisinin pozitif yönlü olduğu görülmektedir. Ayrıca katılımcıların cinsiyet gruplarına göre mutluluk, örgüt performansı ve işe bağlılık tutumları ve alt boyutları için anlamlı farklılık bulunmamaktadır.

Anahtar Kelimeler: Mutluluk, İşe Bă̆lılık, Performans, Örgüt,

\section{Abstract}

In this study, it is aimed to investigate the effect of employees happiness and commitment on organizational performance. In this context, the Oxford Happiness Scale was used to measure the level of happiness of health workers; In order to measure their commitment to work, the Utrecht Work Commitment Scale and Organizational Performance Scale were used to measure organizational performance. The population of the descriptive study was composed of health workers of a private hospital in the center of Kastamonu. 93 healthcare personnel participated in the study as a volunteer. According to the results of the study, it is observed that employees with postgraduate education are happier than those with high school graduates and doctors are happier than nurses. Compared to the physicians and nurses, technicians evaluate the organization performance as low. It is observed that the effect of the engagement perceptions of the participants on organizational performance attitudes is positive. In addition, there were no significant differences between the participants' gender groups according to their happiness, organizational performance and job-related attitudes and sub-dimensions.

Keywords: Happiness, Commitment to Work, Performance, Organization, 


\section{GíRiş}

Mutluluk bireyin bir bütün olarak kendi yaşam kalitesini değerlendirme derecesi olarak ifade edilebilmektedir. Bu sebeple; bireylerin genel mutluluk düzeyine ilişkin algısını, temel yaşam alanlarındaki genel memnuniyetini ölçmek ve bunların zaman içindeki değişimini takip etmek açısından mutluluğa yönelik araştırmaların yapılması önemli görülmektedir. Farklı değerlere ve amaçlara sahip bireyler için farklı değişkenler bireyin mutluluğu üzerinde etkili olabilmektedir. Bu bağlamda; mutlulukla ilgili olarak tek bir neden üzerine odaklanmak çok da yerinde bir yaklaşım olarak görülmemelidir. Nitekim bireylerin mutluluk dereceleri belirlenirken tek bir açıdan bakarak değerlendirme yapılması doğru sonuçlar vermeyebilmektedir (Demirbulat ve Avcıkurt, 2015, s. 91). Tarih boyunca olduğu gibi günümüzde de mutluluk kavramı önemini korumaktadır. Bunun nedeni herkesin mutlu olmak istemesi ve mutluluğun herkes için hayatın amacı olarak nitelendirilebilmesidir (Bülbül ve Giray, 2011, s.113).

Bireyler iş yaşamındaki bir oluşuma veya kavrama kendini ait hissetmek, kendini onun bir parçası olarak görmek veya bu oluşum veya kavramla bir bağ kurmak isteyebilir. Bu oluşum ya da kavram, bireyin örgütü veya işi olabilir. İşe bağl1lığın bireyin işine ilişkin geliştirdiği bir çeşit tutum olduğunu, o işle bir bağ kurduğunu ve o işte kalma arzusunu içerdiğini söylemek mümkündür. Bireylerin iş yaşamına ilişkin geliştirdikleri bu durum, bireyin iş performansını olumlu etkileyebilir. Ayrıca işine bağlı çalışan iş ortamında daha huzurlu olduğundan diğer yaşam alanlarına da bu olumlu tutum yansımaktadır (Kurt, 2013, s. 46-47)

Beklentilerin her geçen gün değiştiği ve rakiplerin yenilikçi adımlarla pazar paylarını büyüttükleri günümüzde örgütsel performansın sağlanması en başta gelen kritik başarı faktörlerindendir. İşletmeler örgütsel performansın artırılmasına yönelik yoğun çaba göstermektedir. Öyle ki küresel rekabet, değişen çevresel koşullar, işletmelerin varlığını sürdürmek ve değişen koşullara uyum için yenilenen stratejiler, işletmelerin örgütsel performansının artırılması için önemli faktörlerdendir (Turunç, 2015, s.18). Günümüz işletmelerinde başarı, birçok faktör belirleyici olsa da ağırlıklı olarak, işletme fonksiyonlarını yerine getiren personelin göstereceği performansa bağlı olmaktadır. Personelden sağlanacak yüksek bir performans işletme amaçlarının, çok daha kısa sürede, çok az hata ile çok daha yüksek kalitede gerçekleştirilmesini sağlayacaktır (Yaralığlu, 2001, s. 129). Örgüt çalışanlarının göstereceği yüksek performans ise çalışanın mutluluğu, motivasyonu, örgüt kültürü, işe bağl1lık gibi etkenlere bağl1 olabilir.

$\mathrm{Bu}$ kapsamda; sağlık çalışanlarının mutluluk düzeylerinin ve işe bağlılıklarının örgüt performansı üzerindeki etkilerinin belirlenmesi, çalışmanın temel amacını oluşturmaktadır. Ayrıca, cinsiyet, yaş, medeni durum, meslek gibi demografik değişkenlerin mutluluk, işe bağlılık ve örgüt performansı üzerindeki etkileri de incelenmiştir.

\section{1. Çalışan Mutluluğu}

Bireyleri mutluluğa sevk edecek güdülerden birisi de öznel iyi oluştur. Literatürde öznel iyi oluş kavramına, birçok düşünür ve sosyal bilimci tarafından farklı şekillerde yaklaşılmıştır. Sosyal bilimciler, insanların hayatlarını olumlu anlamda değerlendirmelerine neyin yol açtığı sorusu üzerine odaklanmışlardır. Bu yaklaşım ile öznel iyi oluş, yaşam doyumu olarak etiketlenmiş ve iyi yaşamın ne olduğunun belirlenmesi katılımcıların standartlarına dayandırılmıştır (Diener, 1984, s. 543). O halde öznel iyi oluş kavramı; bireylerin kendini iyi hissetmesi, yaşamdan haz duyması, pozitif duygularının yüksekliği ve negatif duygularının azlığı/yokluğu olarak ifade edilmektedir (Bardakoğlu vd., 2017, s. 106).

Psikolojide ise, öznel iyi oluş kavramı, mutluluk olarak nitelendirilmektedir (Diener, 1984; Eryılmaz ve Doğan, 2012, s. 50). Literatürde mutlu bir bireyin genel profilini birden çok demografik özelliğe göre belirten ilk araştırmacı Wilson'dur. Araştırmacı bu profili; genç, sağlıklı, iyi eğitimli, iyi ücret alan, dışa dönük, iyimser, kaygısız, dindar, evli, iş erdemi yüksek, makul isteklere sahip, her iki cinsiyetten olabilen ve zeki kişi olarak ifade etmiştir (Kangal, 2013, s. 217). Genel anlamda mutluluk kavramı; yaşam kalitesini pozitif olarak değerlendirme, sağlıklı olma, iyi beslenme, korunma ve barınma ihtiyaçlarını karşılayabilme, refah ve esenlik içinde olma, yaşam doyumu sağlama durumlarıyla ilişkilendirilmektedir (Işık vd., 2017, s. 459). Michalos (2007) ise, mutlu bir insanın; düşük bir düzeyde korku, düşmanlık, gerginlik, kaygı, suçluluk ve öfke gibi durumlara sahip olmasının muhtemel olduğuna; yüksek derecede enerjik, canlı ve aktiviteli; yüksek düzeyde benlik saygısı olan ve duygusal olarak kararlı kişilikli; güçlü sosyal yönelimli; sağlıklı, tatmin edici, sıcak ve sosyal; anlamlı çalışmayla aktif bir yaşam tarzı benimsemiş; nispeten iyimser, endişesiz, günümüze yönelik düşünen ve iyi yönlendirilmiş özelliklerde olduğuna vurgu yapmıştır. 
İlgili yazında, kişilerin mutlu olmalarının yaşamlarının bir parçasını oluşturan çalışma hayatlarında da önemli rol oynadığı düşünülmektedir. Mutlu çalışanların, daha pozitif, işini severek yapan, istekli, diğerlerine yardımcı olmaktan zevk alan, tükenmişlik sendromu yaşama oranı nispeten düşük olan, daha verimli ve yüksek performansla çalışan kişiler olmaları dolayısıyla organizasyonlar için önemli varlıklar olduğuna vurgu yapılmıştır (Yüksekbilgili ve Akduman, 2016, s. 2). Işık vd.'nin (2017) çalışmaları da bunu destekler nitelikte, çalışanların işlerinde tatmine ulaşmasının, mutluluğun bir göstergesi olduğunu ifade etmişlerdir. Ayrıca, çalışanların duygu durumlarının iş yaşamına yansıdığını, mutsuz kişilerin çalışma hayatlarının da negatif yönde etkilendiğini ve bu durumun performans düşüklüğüne sebep olduğunu, mutlu insanların iş memnuniyetlerinin mutsuz olan insanlara nazaran daha fazla olduğunu ve mutluluğun arttıkça iş tatminin de artacağını vurgulamışlardır.

Öte yandan Akduman (2015, s. 102) çalışmasında, mutluluktan iş verimliliğine, işe bağl1lığa ve yüksek performansa doğru olumlu bir etkiden ziyade; işyerinin, çalışanın hayatına anlam katacak ve ona gurur verecek şekilde etkin yönetiminden, çalışanların mutluluğuna doğru olumlu bir etkinin olabileceğini ifade etmişlerdir. Yani, organizasyonların sadece performansı yükseltmeye yönelik çalışmaları benimsemekten öteye geçerek, çalışanların hayatına anlam katacak değerlerin de verildiği bir yapıda olmasının gerektiğini, böylece iş görenin mutlu olacağını, dolayısıyla verimlilik ve performansın da yükseleceğini ifade etmiştir.

\section{2. İşe Bağlılık}

Günümüzde, organizasyonların göz ardı etmemesi gereken en önemli faktör, dört üretim faktöründen biri olan işgücü yani emektir. İş yaşamında verimi yakalayabilmek ve rekabeti etkin bir şekilde yönetebilmek için çalışanların gayretine, motivasyonuna, örgüte ve işe bağlılığına ihtiyaç duyulduğu yöneticiler tarafından da bilinmektedir. $\mathrm{Bu}$ farkındalık, örgüt içinde çalışanları destekleyici, motive edici ve güçlendirici yaklaşımlara önem verilmesini gerektirmektedir.

Çalışmalarında güçlendirme kavramına ağıllıkla değinen Gümüşlüoğlu ve Aygün (2010), işe bağl1lık kavramını güçlendirme kavramı ile ilişkilendirmiştir. Araştırmacılar, güçlendirme kavramının başta davranışsal yaklaşımla açıklandığını ancak zamanla bilişsel yaklaşım ile açıklandığını ifade etmiştir. Bu kavramı bilişsel yaklaşıma göre, yöneticilerin personeli güçlendirmek için yaptıkları faaliyetlerin çalışanların algılayışlarıyla ilişkilendirilmesi olarak tanımlamışlardır. Buna göre, işini anlamlı bulan, işine uygun olduğunu düşünen ve yüksek güçlendirme algısına sahip bir çalışanın, düşük güçlendirme algısına sahip bir çalışana oranla daha çok motive olacağını, işinden daha fazla keyif alacağını dolayısıyla da işine daha fazla bağlanacağını öngörmüşlerdir (Gümüşlüoğlu ve Aygün, 2010, s. 25-26).

İlgili yazın incelemesinde, işe bağlılık kavramının işe tutkunluk ya da işe adanmışlık olarak da çalışmalara konu edildiği tespit edilmiştir. Genel anlamda işe bağlılık Tanrıverdi ve Sarıhan (2013) tarafından, kişinin işine verdiği değer ve işle özdeşleşme olarak tanımlanmaktadır. İşe bağlılık kavramını ilk olarak dile getirdiği düşünülen Kahn (1990) ise bu kavramı, insanların rollerine bağlılığı ve rollerden kopmaları yaklaşımı ile ilişkilendiren Goffman'ın Rol Teorisi ile açılamaktadır (Başoda, 2017, s. 74). Kahn (1990) bu teoriyi, insanların anlık olarak rollerine bağlanması ya da rollerinden uzaklaşması olarak ifade etmektedir. Daha açık bir ifadeyle, insan ve rolleri arasında bir uyumun ya da özdeşleşmenin varlığı halinde rolü benimseme veya kabul etme durumu "kişisel bağlılı"; insan ve rolleri arasında mesafenin ve uyumsuzluğun varlığı halinde rolden uzaklaşma veya soyutlanma durumu "kişisel ayrılık" olarak nitelendirilmiştir. Kişisel bağlanma durumunda çalışanların rol performansları sırasında kendilerini fiziksel, bilişsel ve duygusal olarak istihdam ettiği; kişisel ayrılık durumunda ise çalışanların rol performansları sırasında kendilerini fiziksel, bilişsel veya duygusal olarak geri çekip koruduğu ifade edilmiştir (Kahn, 1990, s. 694).

İşe bağl1lığın; işin yaşam ilgisinin merkezi olması, işe aktif katılım, işin özsaygının merkezi olması ve iş ile psikolojik olarak özdeşleşme durumlarıyla bağlantılı olduğu da literatürde ifade edilmektedir. Buna göre bir iş, kişinin ihtiyaçlarını tatmin etmesine, kişinin göstereceği yüksek performans ile prestij kazanmasına, işiyle ilgili önemli kararların alınmasında aktif rol oynamasına ve dolayısıyla özsaygının artmasına katkı sağladığı takdirde, kişinin işe karşı bağlılığını ve psikolojik olarak özdeşleşmesini artırdığı düşünülmektedir. Öte yandan, kişinin ihtiyaçları dışında işe bağlılığı güçlendiren diğer etkenlerin; kişinin değerleri, demografik özellikleri, kişilik-psikolojik özellikleri, kontrol odaklılık, içsel motivasyon, başarı güdüsü, işin özellikleri ve iş çevresi olarak ifade edilmektedir (Kuruüzüm vd., 2010, s. 184-186).

Literatüre incelendiğinde, Şahin ve Şahin (2016) ise yaptıkları çalışmada, işe bağlılık üzerinde etkili olan bir diğer değişkenin sosyo-kültürel değerlerden biri olan "dindarlık" olabileceğini savunmuştur. Bu 
çalışmanın bulguları ise, kamu kurumlarında dindarlık ve işe bağlılık arasında pozitif bir ilişkinin var olduğu, yani dini duygu ve davranışlara sahip kamu personelinin işine daha bağlı olarak bir performans sergileyeceği yönünde ortaya çıkmıştır.

Korkmaz ve Erdoğan (2014) ise çalışmalarında; genel anlamıyla sağlık, kariyer ve özel yaşamda memnuniyet olarak nitelendirilen iş yaşam dengesinin örgütsel bağlllı̆̆a ve çalışan memnuniyetine etkisinin olup olmadığını araştırmıştır. Sonuç olarak da, iş yaşam dengesinin örgütsel bağlılığı arttırdığg fakat çalışan memnuniyeti üzerinde doğrudan anlamlı bir etkisinin olmadığı ortaya konulmuştur. Ancak diğer yandan, örgütsel bağl1lığın çalışan memnuniyetini arttırdığı tespit edilmiştir.

\section{3. Örgütsel Performans}

Performans kavramı literatürde genellikle bireysel ve örgütsel olmak üzere iki boyut altında incelenmektedir. Bireysel performans da kendi içinde görev performansı ve durumsal performans boyutlarıyla ilişsilendirilmektedir. Görev performansı davranışları bir kişinin mesleği ve işi ile ilgili temel teknik beceri ve faaliyetlerini; durumsal performans davranışları ise meslektaş ve mesai arkadaşlarına yardımcı olma, ekstra çaba sarf etme ve örgütünü geliştirme gibi unsurları içermektedir (Gül, 2007, s. 324).

Örgütsel anlamda performans, bir örgütün kendi geçmişine veya sektöre, dış çevreye, rakiplerine nazaran daha etkili ve verimli olması olarak ifade edilebilmektedir. Performans, bugün ve gelecekle ilgili bir kavram olup, kaynak etkinliği ve verimliliğiyle örgütün sürekliliğini sağlayarak amaçlarına ulaşmasına yardımcı olmaktadır (Usta, 2010, s. 34-35). Bu durumda örgütsel performans, örgütün amaçlarını ne ölçüde gerçekleştirdiğiyle ilgilidir (Yeşil vd., 2016, s. 155).

Örgütler, günümüz küresel rekabet ortamında hangi konumda olduklarını ve amaçlarına ne derecede ulaştıklarını saptamak için ise; karlılık, ciro, üretim miktarı, maliyetler ve piyasa değeri gibi nicel (finansal) göstergeler ya da verimlilik, kalite, müşteri tatmini, üretimde değer yaratma, teknolojik yeterlilik, yeni ürün geliştirme, pazar payı gibi nitel (finansal olmayan) ölçütler kullanabilmektedir (Eren ve Kaplan, 2014, s. 177).

\section{GEREÇ VE YÖNTEM}

Araştırmanın evrenini Kastamonu il merkezinde yer alan 78 yataklı özel bir hastanede görevli 152 sağlık çalışanı oluşturmaktadır. Araştırmada örneklem alınmamış olup, evrenini tamamına ulaşılmak hedeflenmiştir. 93 sağlık çalışanı araştırmaya katılmaya gönüllü olmuştur. Araştırmada veri toplama aracı olarak 4 bölümden oluşan bir anket formu kullanılmıștır. Birinci bölümde demografik faktörler yer alırken, ikinci bölümde çalışan mutluluğunu değerlendirmeye yönelik sorulara yer verilmiştir. İkinci bölümde yer alan sorular, Hills ve Argyle'in (2002) çalışmasında yer alan “Oxford Mutluluk Ölçeği”nin, Doğan ve Çötok (2011) tarafindan kısa formunun Türkçe'ye uyarlanmış halidir. Üçüncü bölümde yer alan Schaufeli, ve diğerleri (2002) tarafından geliştirilen "Utrecht İșe Bağllık Ölçeği” ise Eryılmaz ve Doğan tarafından Türkçe'ye uyarlanmıştır. "İşe Bağl1lık Ölçeği" işe istek duyma, işe adanma ve işe yoğunlaşma alt boyutlarından oluşmaktadır. Dördüncü bölümde ise performans düzeyini belirlemek üzere Tseng ve Lee'nin (2009) “Örgütsel Performans Ölçeği” kullanılmıştır.

$\mathrm{Bu}$ araştırmanın temel amacı çerçevesinde, bağımlı değişkeni örgüt performansı; bağımsız değişkenleri ise çalışan mutluluğu ve işe bağlılık olarak belirlenmiştir. Araştırma tanımlayıcı bir çalışma olup, veriler 15-25.07.2018 tarihleri arasında toplanmıştır. Çalışmada kullanılan ölçeklerin güvenilirlikleri Cronbach Alpha katsayısının tespit edilmesi suretiyle belirlenmiştir. Bu doğrultuda, araştırmanın mutluluk ölçeği için $\alpha=0,71$ işe bağl1lık ölçeği için $\alpha=0,87$ ve örgüt performansı için $\alpha=0,91$ olarak bulunmuştur. Bu sonuçlar özellikle sosyal bilimler alanında gerçekleştirilen araştırmalar için yüksek düzeyde güvenilir sonuçlar olarak kabul edilmektedir.

Araştırma verileri bilgisayar ortamına aktarılarak SPSS 20.0 programında analiz edilmiştir. Araştırma verileri değerlendirilirken tanımlayıcı istatistikler (yüzde, frekans, ortalama, standart sapma) hesaplanmış, karşılaştırmalı analizlerde parametrik test varsayımlarının yerine getirildiği durumlarda bağımsız iki grup arası karşılaş̧ırmalarda t-testi ve tek yönlü varyans analizi (ANOVA) kullanılmıştır. Tanımlayıcı istatistikler sürekli değişkenler için ortalama \pm standart sapma, kategorik değişkenler için $n$ ve \% şeklinde gösterilmiştir. Çalışma verileri \%95 güven aralığında ve iki yönlü olarak değerlendirilmiş, anlamlılık düzeyi $\mathrm{p}<0,05$ olarak kabul edilmiştir. 


\section{BULGULAR}

Araştırmaya katılan hastane çalışanların kişisel özelliklerine ait frekans ve yüzde dağılımı Tablo 1'de verilmiştir. Tablo 1'e bakıldığında ankete katılanların \%68.8'i kadın, \%31.2'si erkektir. Yaş gruplarına bakıldığında ankete katılanların \%67.7'si otuz yaşın altındadır. Buradan hastane çalışanlarının yaş ortalamalarının genç olduğu görülmektedir. İşletmede çalışma süresi bakımından 1-5 yıl çalışma süresine sahip olanların oranı \%54.2'dir. Araştırmaya katılanların medeni durumlarına bakıldığında \%50.5'i bekar, \%49.5'i evlidir. Çalışanlar eğitim durumu açısından değerlendirildiğinde \%54.3'ünün lise mezunu olduğu görülmektedir. Araştırmaya katılan hastane çalışanlarının \%50.7'si hemşire ve ATT, \%24.7'si tıbbi sekreter, $\% 16.1$ 'i teknisyen ve \%8.6's1 hekimdir.

Tablo 1. Çalışanların Demografik Verileri

\begin{tabular}{|c|c|c|c|c|c|c|c|}
\hline \multicolumn{2}{|l|}{ Kişisel Bilgiler } & \multirow{2}{*}{$\frac{N}{64}$} & \multirow{2}{*}{$\frac{\%}{68.8}$} & \multicolumn{2}{|c|}{ Kişisel Bilgiler } & \multirow{2}{*}{$\frac{\mathbf{N}}{46}$} & \multirow{2}{*}{$\frac{\mathbf{\%}}{49.5}$} \\
\hline & Kadın & & & Medeni & Evli & & \\
\hline Cinsiyet & Erkek & 29 & 31.2 & Durum & Bekar & 47 & 50.5 \\
\hline \multirow{4}{*}{ Eğitim } & Lise & 50 & 54.3 & \multirow{4}{*}{ Yaş } & $20-29$ & 63 & 67.7 \\
\hline & Önlisans & 18 & 19.6 & & $30-39$ & 20 & 21.5 \\
\hline & Lisans & 18 & 19.6 & & $40-49$ & 8 & 8.6 \\
\hline & Lisansüstü & 6 & 6.5 & & 50 ve üstü & 2 & 2.2 \\
\hline \multirow{4}{*}{$\begin{array}{l}\text { İşletmede Ça } \\
\text { lışma Süresi }\end{array}$} & 1 y1ldan az & 8 & 9.6 & \multirow{4}{*}{ Meslek } & Hekim & 8 & 8.6 \\
\hline & $1-5 \mathrm{y} 1 \mathrm{l}$ & 45 & 54.2 & & Hemşire-ATT & 47 & 50.7 \\
\hline & $6-10$ y1l & 20 & 24.1 & & Tibbi Sekreter & 23 & 24.7 \\
\hline & 11 yıl ve üzeri & 10 & 12 & & Teknisyen (Lab, Anestezi, Röntgen vs.) & 15 & 16.1 \\
\hline
\end{tabular}

Tablo 2 incelendiğinde, araştırma kapsamında çalışanların mutluluk, örgüt performansı, işe bağlılık ve alt boyutlarının aritmetik ortalamaları ve standart sapmaları verilmiştir. Mutluluk ölçeğinin geneli için ortalama $X=3.43$; örgüt performansı ölçeğinin geneli için $X=3.82$; işe bağl1lık ölçeğinin geneli için ise $X=3.72$ olarak tespit edilmiştir. Buradan çalışanların mutluluk, işe bağlılık ve örgüt performans düzeylerinin yüksek olduğu söylenilebilir. Alt boyutlarda da işe bağl1lık düzeylerinin ortalamanın üzerinde olduğu görülmektedir.

Tablo 2. Ölçeklere Ait Aritmetik Ortalama ve Standart Sapma Değerleri

\begin{tabular}{lcc}
\hline Ölçek & Mean $(\mathbf{X})$ & Standart Sapma (S.S.) \\
\hline Mutluluk & 3.43 & 0.61 \\
Performans & 3.82 & 0.67 \\
İșe Bağlı̀k (İB) & 3.72 & 0.64 \\
$\quad$ İB-İșe İstek Duyma & 3.53 & 0.80 \\
$\quad$ İB-İşe Adanma & 4.16 & 0.57 \\
$\quad$ İB-İșe Yoğunlaşma & 3.53 & 0.71 \\
\hline
\end{tabular}

Araştırmaya katılanların kişisel özellikleri olarak tanımlanan yaş, eğitim, cinsiyet, medeni durum, çalışma süresi, mesleğe göre 0,05 anlamlılık düzeyinde istatistiksel olarak anlamlı bir farklılık gösterip göstermediği t testi, GamesHowell testi ve Welch testi ile analiz edilmiştir. 
Tablo 3. Katılımcıların Mutluluk, Performans ve İşe Bağlılık Algılarının Eğitim Durumuna Göre Welch Analizi Bulguları

\begin{tabular}{lccc}
\hline Değişken & İstatistik & Serbestlik Derecesi & $\mathbf{p}$ \\
\hline Mutluluk & 4.135 & 3 & $\mathbf{0 . 0 1 9}$ \\
Performans & 2.832 & 3 & 0.065 \\
İșe Bağlılık & 2.215 & 3 & 0.117 \\
$\quad$ İB-İşe İstek Duyma & 1.729 & 3 & 0.192 \\
$\quad$ İB-İșe Adanma & 2.042 & 3 & 0.139 \\
$\quad$ İB-İșe Yoğunlaşma & 2.325 & 3 & 0.105 \\
\hline
\end{tabular}

Tablo 3'e göre katılımcıların eğitim durumları ile mutluluk, örgüt performansı ve işe bağl1lık arasındaki farkın tespiti için ise varyansların homojen olmadığı durumlarda başvurulan testlerden biri olan Welch ve GamesHowell uygulanmıştır. Buna göre mutluluk değişkeni $(p=0.019)$ için anlamlı fark bulunmuştur. Lisansüstü mezunu çalışanların lise mezunu çalışanlara göre daha mutlu olduğu söylenilebilir.

Tablo 4. Katılımcıların Mutluluk, Performans ve İșe Bağlılık Algılarının Mesleğe Göre Welch Analizi Bulgular1

\begin{tabular}{lccc}
\hline Değişken & İstatistik & Serbestlik Derecesi & p \\
\hline Mutluluk & 2.920 & 5 & $\mathbf{0 . 0 3 4}$ \\
Performans & 3.386 & 5 & $\mathbf{0 . 0 1 9}$ \\
İșe Bağlı̀ık & 0.078 & 5 & 0.511 \\
İB-İşe İstek Duyma & 0.604 & 5 & 0.698 \\
İB-İşe Adanma & 2.061 & 5 & 0.106 \\
İB-İş̧e Yoğunlaşma & 0.466 & 5 & 0.797 \\
\hline
\end{tabular}

Tablo 4'e göre katılımcıların mesleki durumlarına göre mutluluk ( $\mathrm{p}=0.034)$ ve örgüt performans1 $(\mathrm{p}=0.019)$ için anlamlı fark bulunmuştur. Hekimlerin hemşirelere göre daha mutlu görülmektedir. Yine teknisyenlerin hekim ve hemşirelere göre örgüt performansını düşük olarak değerlendirdiği ifade edilebilir.

Araştırmaya katılanların cinsiyet gruplarına göre mutluluk $(p=0.16)$, örgüt performansı $(p=0.83)$ ve işe bağl11ık $(\mathrm{p}=0.29)$ tutumları ve alt boyutları için anlamlı farklılık bulunamamıştır. Araştırmaya katılanların medeni durumlarına göre mutluluk $(p=0.75)$, örgüt performansı $(p=0.28)$, ve işe bağl1l1k $(p=0.21)$ tutumları ve alt boyutları için anlamlı farklılık bulunamamıştır. Araştırmaya katılanların yaş gruplarına göre mutluluk $(\mathrm{p}=0.47)$, örgüt performansı $(\mathrm{p}=0.16)$, ve işe bağl1lık $(\mathrm{p}=0.30)$ tutumları ve alt boyutları için anlamlı farklılık bulunamamıştır. Araştırmaya katılanların çalışma sürelerine göre mutluluk $(\mathrm{p}=0.53)$, örgüt performansı $(\mathrm{p}=0.28)$ ve işe bağlılık $(\mathrm{p}=0.97)$ tutumları ve alt boyutları için anlamlı farklılık bulunamamıştır.

Tablo 5. Mutluluk, Performans ve İşe Bağl1lığa İlişkin Regresyon Analizi

\begin{tabular}{|c|c|c|c|c|c|}
\hline \multirow{3}{*}{ Model } & \multicolumn{2}{|c|}{ Standardize Edilmemiş } & \multirow{3}{*}{$\begin{array}{c}\text { Standardize Edilmiş } \\
\text { Katsayı } \\
\text { Beta }\end{array}$} & \multirow{3}{*}{$\mathbf{t}$} & \multirow{3}{*}{ Sig. } \\
\hline & & & & & \\
\hline & B & Std. Hata & & & \\
\hline Sabit & 1,572 & ,447 & & 3,521 & ,001 \\
\hline Mutluluk & ,190 & ,104 & , 173 & 1,817 & ,072 \\
\hline
\end{tabular}


Araştırmaya katılanların işe bağlılık algılarının örgüt performansı tutumları üzerindeki etkisinin pozitif yönlü olduğu görülmektedir $(\beta=0,412)$. Bu kapsamda hastane çalışanlarının işe bağlılık düzeyleri arttıkça, örgüt performansına yönelik tutumlarının da artacağını söylemek mümkündür. Mutluluk algılarının örgüt performansı üzerindeki etkisi için ikili regresyon testi de yapılmış olup \%0,08 oranında etki ettiği sonucu ortaya çımıştır $(\mathrm{f}=0,06$, R Square $=0,08)$

\section{TARTIŞMA VE SONUÇ}

$\mathrm{Bu}$ araştırma sağlık çalışanlarının işe bağlılık düzeyinin ve mutluluğun örgüt performansına etkisini incelemiştir. Bir bütün olarak değerlendirildiğinde, katılımcıların mutluluk, işe bağl1lık ve örgüt performans düzeylerinin yüksek olduğu görülmektedir. Alt boyutlarda da katılımcıların işe bağlılık düzeylerinin ortalamanın üzerinde olduğu görülmektedir. Bu kapsamda iș yükü, adalet, motivasyon, aidiyet gibi ișe bağlılı̆̆1 etkileyen unsurlarla ilgili olarak kurumun sağlık çalışanlarını olumlu anlamda desteklediği ifade edilebilir. Ayrıca, lisansüstü mezunu çalışanların lise mezunu çalışanlara göre hekimlerin hemşirelere göre daha mutlu saptanmıştır. Bu durum çalışanların eğitim düzeyi arttıkça görev ve unvanların da artmasına bağlı olarak özgüvenlerinin ve ekonomik durumlarının da yükselmesi ile ilişkilendirilebilir. Yine teknisyenlerin hekim ve hemşirelere göre örgüt performansını düşük olarak değerlendirdiği sonucuna ulaşılmıştır. Çalışma sonucunda çalışan mutluluğunun ve işe bağlılığın örgüt performansını olumlu etkilediği görülmüştür. Bu yüzden yöneticiler çalışanların mutluluğunu değerlendirmeye ve artırmaya yönelik çalışanlarla iş birliği içinde olmalı, özellikle işe bağlılı̆̆ı artırmak için ödüllendirme, iletişim ve ekip çalışmasına önem vermelidir.

İşe bağl1lık çalışanın işini yaparken keyif alması, işiyle bütünleşmesidir. Bu yüzden işe bağlılı̆̆ yüksek kişi kendini işiyle birlikte tanımlar (Gök, 2015, s. 281). Bu düşünce ile yola çıktı̆̆ımız çalışmamız literatürle paralellik göstermektedir. Benzer olarak Öztürk vd. (2011) muhasebe meslek mensupları ile yaptıkları çalışmada katılımcıların büyük çoğunluğunun işlerine bağlı oldukları sonucuna ulaşmışlardır. Negiz ve diğerlerinin (2011) kamu ve özel sektör çalışanları üzerinde yaptıkları çalışmada, çalışanların işe bağlılık durumlarının cinsiyete göre farklılık göstermediği sonucu ortaya çıkmıştır. Ancak Kuruüzüm vd.'nin (2010) çalışması hizmet sektöründe çalışanların cinsiyetlerinin işe bağlılığı etkilediğini göstermiştir. Tabbodi'nin (2009) çalışmasında ise benzer koşullarda kadınların erkeklere göre daha yüksek bağlılık derecesine sahip olduğu ifade edilmiştir. Yine aynı çalışmada işe bağlılık davranışı ile yaş arasında da pozitif bir ilişki olduğunu kanıtlanmıştır. Bu bulgu Marshall, Lask ve Moncrief'in (2004) araştırmasıyla benzerlik göstermektedir. Marshall, Lask ve Moncrief (2004) satış görevlileri ile bir alan araştırması yapmışlar ve işe bağlılık ile demografik özellikler, iş durumu ve piyasa değişkenleri arasındaki ilişkiyi incelemiş̧lerdir. Araştırmada satış görevlilerinin işe bağlılığı ile yaş arasında anlamlı bir ilişki bulunmuştur. Amangala'nın (2013) çalışmasında da genç çalışanların işletmeye çok fazla katkı sağlamamış olmaları nedeniyle bağlılıklarının az olduğu sonucu ortaya çıkmıştır. Ancak bu çalışmada, sağlık çalışanlarında yaşın işe bağlılık üzerinde bir etkisi olmadığı görülmüştür. Bu durumda her yaş grubundaki katılımcının birbiri ile uyumlu çalıştığı, dolayısıyla da işe bağlılıklarının arttığı söylenilebilir.

Yapılan analizler sonucunda, sağlı çalışanlarının mutluluk düzeylerinin yüksek olduğu görülmüştür. Mutluluk, bireyin bir bütün olarak kendi yaşam kalitesini değerlendirme derecesi olarak tanımlanırken, bireylerin genel mutluluk düzeyine ilişkin algısını, temel yaşam alanlarındaki genel memnuniyetini ölçmek ve bunların zaman içindeki değişimini takip etmek açısından mutluluğa yönelik araştırmaların yapılması önemli görülmektedir (Demirbulat ve Avcıkurt, 2015).

Mutluluğu koruma ve iyiliğin merkezinde kişisel özellikler ile davranışlar arasındaki etkileşim yer almaktadır (Tkach ve Lyubomırsky, 2006, s. 217). Yüksekbilgili ve Akduman (2016) tarafından yapılan bir çalışmada sağlık personellerinin mutluluk düzeylerinin, personelin cinsiyetine göre değişmediği sonucunu ortaya çıkmıştır. Kangal (2013) kadın ve erkek arasındaki mutluluk farklılıklarına bakıldığında literatürde tam bir ayrımın yapılmadığını ve cinsiyetin mutluluk için belirleyici olmadığı ifade etmiş̧tir. Ancak Yaprak vd.'nin (2018) çalışmasında ise kadınların erkeklerden daha mutlu olduğu görülmüştür. Bu çalışmada ise, sağlık çalışanlarında cinsiyetin mutluluk üzerinde bir etkisi olmadığı sonucu ortaya çıkmıştır.

Uzun süreli bir mutluluk duygusunun, değerlerin ve hedeflerin bir kısmının gerçekleşmesinden kaynaklanmas1 da muhtemeldir (Diener vd., 1998, s. 35). Bu bağlamda Easterlin'in (2003) mutluluğu açıklamak üzere yaptığı çalışmada evli bireylerin bekârlara göre daha mutlu olduğu sonucuna ulaşılmıştır. Benzer bir şekilde Bülbül ve Giray'ın (2011) çalışmasında da medeni durum ile mutluluk arasında anlamlı bir ilişki bulunduğu saptanmış; medeni durumu evli olan bireylerin mutluluğa daha yakın oldukları görülmüştür. 
Yüksekbilgili ve Akduman (2016) tarafından yapılan bir çalışmada sağlık personellerinin mutluluk düzeylerinin, personelin eğitimine göre değişmediği sonucunu ortaya çıkmıştır. Ancak Zagorski vd.'nin (2010) ekonomik gelişme ve mutluluğu inceledikleri çalışmada yüksek eğitimli kişilerin, düşük eğitim seviyesine sahip ülkelerdeki daha az eğitimli akranlarından daha mutlu oldukları görülmüsstür. Yine Bülbül ve Giray'ın (2011) çalışmasında da eğitim seviyesi ile mutluluk değişkenleri arasında anlamlı bir ilişki olduğu tespit edilmiş; eğitim düzeyi yüksek bireylerin mutluluğa daha yakın oldukları görülmüştür. Benzer bir şekilde bu çalışmada lisansüstü eğitime sahip bireylerin lise mezunu bireylere göre daha mutlu oldukları sonucu ortaya çıkmıştır.

Kamu ve özel sektör kuruluşlarının amaçlarına ulaşma durumlarının belirlenmesi ve başarılarının sürdürülebilirliğinin değerlendirilmesi açısından performans önemli bir araçtır (Usta, 2010, s. 33). Bu bağlamda turizm sektörü çalışanları ile yapılan bir araştırmada, işe bağlılığın iş performansına yansımasıyla işletme performansının da olumlu etkilendiği belirtilmiştir (Kurt, 2013, s. 79). Bu çalışmada da benzer şeklide işe bağlılık ile örgüt performansı arasında pozitif yönlü bir ilişki olduğu sonucu ortaya çıkmıştır. Katılımcıların, sağlık kurumlarının önemli bir özelliği olan ekip çalışmasını desteklemesi ile birlikte örgüt performansının arttığg düşünülebilir.

\section{KAYNAKÇA}

Akduman, G. (2015). Çalışan Mutluluğunun İşe İlişkin Duyuşsal İyilik Algısı ile İlişkisi ve Kuşaklar Arasındaki Farklılıkların İncelenmesi, Doktora Tezi, İstanbul Arel Üniversitesi, İstanbul.

Amanga, TA. (2013). The Effect of Demographic Characteristics on Organisational Commitment: a Study of Salespersons in the Soft Drink Industry in Nigeria, European Journal of Business and Management, 5(18), 109-118.

Asunakutlu, T. (2002). Örgütsel Güvenin Oluşturulmasına İlişsin Unsurlar ve Bir Değerlendirme, Muğla Üniversitesi Sosyal Bilimler Enstitüsü Dergisi, 9, 1-13.

Atilla Gök, G. (2015). "Presentable” Duygusal Emek: İlaç Mümessillerinde Duygusal Emeğin İşe Bağl1lığa Etkisi, Eskişehir Osmangazi Üniversitesi İİBF Dergisi, 10(3), 277-300.

Bardakoğlu, Ö., Akgündüz, Y., Kızılcalığlu, G. ve Yeşilyurt, H. (2017). Otel İşletmelerinde Algılanan Yönetici Desteğinin Çalışanların İş Stresi ve Mutluluk Düzeylerine Etkisi, 8. Uluslararası Girişimcilik Kongresi, 103-115.

Başoda, A. (2017). İşe Tutkunluk: Kavramsal Açıdan Bir İnceleme, Uluslararası Tarih ve Sosyal Araştırmalar Dergisi, 17, 71-98.

Bülbül, Ş ve Giray, S. (2011). Sosyo-demografik Özellikler ile Mutluluk Algııı Arasındaki İlişki Yapısının Analizi, Ege Akademik Bakış, 11 (Özel Sayı), 113-123.

Çalışkan, A., Akkoç, İ ve Turunç Ö. (2011). Örgütsel Performansın Artırılmasında Motivasyonel Davranışların Rolü: Yenilikçilik ve Girişimciliğin Aracılık Rolü, Süleyman Demirel Üniversitesi İktisadi ve İdari Bilimler Fakültesi Dergisi, 16(3):363-401.

Deiner, E. (1984). Subjective Well-Being, Psychological Bulletin, 95(3), 542-575.

Diener, E, Sapyta, JJ ve Suh E. (1998) Subjective Well-Being is Essential to Well-Being, Psychological Inquiry, 9(1):33-37.

Demirbulat Ö.ve Avcıkurt, C. (2015). Turizm ve Mutluluk Arasındaki İlişki Üzerine Kavramsal Bir Değerlendirme, Balıkesir Üniversitesi Sosyal Bilimler Enstitüsü Dergisi, 18(34).

Doğan, T ve Çötok, N. A. (2011). Oxford Mutluluk Ölçeği Kısa Formunun Türkçe Uyarlaması: Geçerlilik ve Güvenirlik Çalışması, Türk Psikolojik Danışma ve Rehberlik Dergisi, 4(36), 165-172.

Easterlin, RA. (2003). Explaining Happiness, PNAS, 100(19), 11176-11183.

Eren, M.Ş. ve Kaplan, M. (2014). Kurumsal Yetkinliklerin Örgütsel Performans Üzerindeki Etkileri: Üretim Firmaları Üzerine Bir Araştırma, Dumlupınar Üniversitesi Sosyal Bilimler Dergisi, 40, 175-192. 
Eryılmaz, A. ve Doğan, T. (2012). İş Yaşamında Öznel İyi Oluş: Utrecht İşe Bağlılık Ölçeğinin Psikometrik Niteliklerinin İncelenmesi, Klinik Psikiyatri Dergisi, 15(1), 49-55.

Gumusluoglu, L. ve Aygün, Z. (2010). Bilgi Çalışanlarının Adalet ve Güçlendirme Algılarının Örgüte, Lidere ve İşe Bağll1ık Üzerindeki Etkileri, Türk Psikoloji Dergisi, 25(66), 21-36.

Gül, H. (2007). İş Stresi, Örgütsel Sağlık ve Performans Arasındaki İlişkiler: Bir Alan Araştırması, Karamanoğlu Mehmetbey Üniversitesi Sosyal ve Ekonomik Araştırmalar Dergisi, 2007(2): 318-332.

Hills, P. ve Argyle, M. (2002). The Oxford Happiness Questionare: A Compact Scale For The Measurement of Psychological Well-Being, Personality and Individual Differences, 33, 10731082.

Işık, Z., Çetinkaya, N. ve Işık, M.F. (2017). Mutluluğun İş Tatmini Üzerindeki Rolü: Erzurum İli Palandöken Kış Turizm Merkezinde Yer Alan Konaklama İşletmelerindeki Kadın Çalışanlar Üzerine Bir Uygulama, Atatürk Üniversitesi Sosyal Bilimler Enstitüsü Dergisi, 21(2), 457471.

Kahn, W.A. (1990). Psychological Conditions of Personal Engagement and Disengagement at Work, Academy of Management Journal, 33(4), 692-724.

Kangal, A. (2013). Mutluluk Üzerine Kavramsal Bir Değerlendirme ve Türk Hanehalkı İçin Bazı Sonuçlar" Elektronik Sosyal Bilimler Dergisi, 12(44), 214-233.

Korkmaz, O. ve Erdoğan, E. (2014). İş Yaşam Dengesinin Örgütsel Bağlılık ve Çalışan Memnuniyetine Etkisi, Ege Akademik Bakış, 14(4), 541-557.

Kurt, E. (2013). Algılanan Sosyal Destek ve İş Performansı İlişkisinde İşe Bağlılığın Aracı Etkisi: Turizm İşletmelerinde Bir Araştırma, Hacettepe Üniversitesi Sosyal Bilimler Enstitüsü İşletme Anabilim Dalı Yönetim Organizasyon ve Örgütsel Davranış Bilim Dalı, Yüksek Lisans Tezi, Ankara.

Kuruüzüm, A., Irmak, S. ve İpekçi Çetin, E. (2010). İşe Bağl1lığı Etkileyen Faktörler: İmalat ve Hizmet Sektörlerinde Karşılaştırmalı Bir Analiz, Bilig Ahmet Yesevi Üniversitesi Mütevelli Heyet Başkanlığı, 53, 183-198.

Marshall, GW. Lassk, FG., Moncrief, WC (2004). Salesperson Job Involvement: Do Demographic, Job Situational, and Market Variables Matter?, Journal of Business \& Industrial Marketing, 19, 337-343.

Michalos, A.C. (2007) Education, Happiness and Wellbeing, Erişim 12 Ocak 2019, https://www.oecd.org/site/worldforum06/38303200.pdf.

Negiz, N. Oksay, A. ve Akman, E. (2011). İşe Bağlılık ve İşten Tatmin Açısından Cinsiyet ve Sektörel Farklılık: Kamu ve Özel Sektör Kuruluşlarında Karşılaştırmalı Bir İnceleme (Isparta Örneği), Süleyman Demirel Üniversitesi Sosyal Bilimler Enstitüsü Dergisi, 2, 207-229.

Öztürk, V., Çil Koçyiğit S. ve Çına Bal, E. (2011). Muhasebe Meslek Mensuplarının Mesleki Tükenmişlik Düzeyleri İle İşe Bağlılık Arasındaki İlişkiyi Belirlemeye Yönelik Bir Araştırma: Ankara İli Örneği, Doğuş Üniversitesi Dergisi, 12 (1), 84-98.

Şahin, B. ve Şahin, İ. (2016). Dindarlığın Kamu Personelinin İşe Bağlılığı Üzerindeki Etkisi: Yapısal Eşitlik Modeli Çalışması, Selçuk Üniversitesi Sosyal Bilimler Enstitüsü Dergisi, (35), 249260.

Tabbodi, ML. (2009). Effects of Leadership Behaviour on The Faculty Commitment of Humanities Departments in The University of Mysore, India: Regarding Factors of Age Group, Educational Qualifications And Gender, Educational Studies, 35:1, 21-26, DOI: 10.1080/03055690802288510.

Tanrıverdi, H. ve Sarıhan, M. (2013). İşe Bağl1lığın Tükenmişlik ve Depresyon Düzeyleri Üzerindeki Etkileri: Sağlık Çalışanları Üzerinde Bir Araştırma, Uluslararası İşletme ve Yönetim Dergisi, $1(2), 206-228$. 
Tkach, C. ve Lyubomirsky, S. (2006). How Do People Pursue Happiness?: Relating Personality, Happiness-Increasing Strategies, And Well-Being, Journal of Happiness Studies, 7, 183-225.

Tseng, YF. ve Lee, TZ. (2009). Comparing Appropriate Decision Support of Human Resource Practices on Organizational Performance with DEA/AHP Model, Expert Systems with Applications, 36, 6548-6558.

Turunç, Ö. (2015). Stratejik Yönetim Örgütsel Performans İlişkisinde Kişi-Örgüt Uyumunun Rolü, Uluslararasi İktisadi ve İdari Bilimler Dergisi, 1 (1), 16-30.

Usta, A. (2010). Kamu Kurumlarında Örgütsel Performans Yönetim Süreci, Sayıştay Dergisi, 21(78), 31-58.

Yaprak, P., Güçlü, M. ve Ayy1ldız Durhan, T. (2018) The Happiness, Hardiness, and Humor Styles of Students with a Bachelor's Degree in Sport Sciences, Behavioral Science, 8(9), 82-103, doi:10.3390/bs8090082.

Yeşil, S., Doğan, İ.F. ve Doğan, Ö. (2016). Örgüt Kültürünün Girişimcilik Yönelimi ile Örgütsel Performans Üzerindeki Etkisi: Kahramanmaraş İli Tekstil Sektörü Örneği, Yönetim ve Ekonomi Araştırmaları Dergisi, 14(1), 150-172.

Yüksekbilgili, Z. ve Akduman, G. (2016). Sağlık Personelinin Mutlulukları Üzerine Bir Alan Araştırması: Aile Sağlı̆̆ Merkezlerinde Bir Uygulama, Finans Ekonomi ve Sosyal Araştırmaları Dergisi, 1(1), 71-84.

Zagorski, K. Kelley, J., ve Evans, M. D. R. (2010). Economic Development and Happiness: Evidence from 32 Nations, Polish Sociological Review, 169 (1), 3-19. 